\title{
Dave Rand, VFX artist
}

Dave Rand is a visual effects artist and activist with stints at some of the bestrecognized firms in the business, including Disney, Rhythm \& Hues, Sony Pictures Imageworks, and Digital Domain. His film credits include Frozen (2013) and Life of $\mathrm{Pi}$ (2012), among others. Here Rand describes the precarious and mobile lifestyle of a VFX artist and recounts what it was like for employees at Rhythm \& Hues when the celebrated firm filed for bankruptcy in 2013.

You've worked for a lot of different companies in a lot of different places. Your longest stretch with one company was four years, correct?

Yes, and it's not because I wanted to leave that particular company. I've fallen in love with at least six visual effects companies and never would have left if it weren't for other things that happened. Five of them went bankrupt; the other I left for creative reasons. But I've never been asked to leave, you know? They always wanted to keep me on.

Even when you were working on big, successful feature films, it didn't mean the VFX company benefited. For example, you worked on The Matrix Reloaded (2003), a blockbuster at the box office, but the VFX company went bankrupt.

It happened like this: I was working at Centropolis and they called everyone in for an unscheduled meeting. I have never been in a last-minute Friday meeting that's been anything but, "Your paychecks are going to stop," or, "We're going fucking bankrupt." This was my first one. I'd already been prewarned that if we went 
into dailies on Friday and the lights were on, it meant that the place was closing. As I'm walking out of the meeting, I noticed one guy's cell phone rang, and then another guy's cell phone rang, and I knew they were key players in the movie. And then mine rang. It was the head of recruiting at Sony Pictures Imageworks saying, "Come on over!" So I went over to Sony to finish The Matrix.

What Sony didn't tell me is that they were starting over from scratch. I thought I was just going there to finish up some shots. No, they were starting over. They had ninety days until the release date, and so they hired everybody in Los Angeles. We had to be at dailies every morning at eight and work until we dropped dead. There wasn't a day off. We were fed rows of Fatburgers and fries and pizza and Chinese food. It was tough. It was The Matrix, so it was fun. But it was rugged.

When it was over, all I wanted was to go to Belize for a break. I had a little place down there. And they're like, "You can't leave." They were going to do a Will Smith movie. "We've got to have you on Bad Boys II." But my deal had already expired. So I'm like, "Nah, I'm going to Belize. When I get back if you guys want to hire me, it'd be great." They threatened me! They thought I'd signed a contract. I'm not that stupid; I had an expired deal memo. So I left.

When I got back three weeks later they were apologetic. I said, "You ruined my vacation for a while." They said, "Oh, don't worry! We've got all this work for you!" So I sat for two weeks, and there was nothing to do. Something was on hold. That's the thing with VFX companies: their clients always put stuff on hold. That's how the major studios killed Rhythm \& Hues. How is the shop supposed to pay seven hundred people until you decide to put your movie back on line?

Then I get offered a job on The Chronicles of Riddick (2004) from an outfit called Hammerhead. I checked it out and I loved the show. I told Sony, "I'm outta here. Two weeks' notice, whatever you want to do. You guys haven't been giving me anything to do anyway; everything is on hold." I hadn't signed the contract yet. They were pissed.

Riddick was a cool experience in the beginning. Hammerhead wasn't geared up to do a big 3D show. They made some decisions that were not, I think, the best decisions. I tried to offer my opinion based on my experience. It didn't go down well with them. So I left Hammerhead, and I think I went to Meteor Studios after that, a Canadian company.

Meteor was an incentive-based company. The tax incentives weren't as dramatic as they are today. It proved to be a nightmare, and that's where my story starts, as far as becoming way more active in the politics, business decisions, and business models that visual effects uses. It's because of what happened at Meteor Studios.

I was a supervisor and we began work on Journey to the Center of the Earth (2008). Big movie. Brendan Fraser. A lot of water effects, which has become my favorite thing to do. And right away there were issues with the director. Things were changing a lot, and I'm thinking, "I can't imagine they bid enough to cover all 
these changes." And then I heard that when Meteor submitted change orders to the studio, they were rejected. Meanwhile, I'd be in meetings with all the supervisors each morning. These things would come up and our producer would say, "Don't worry about it. Just keep working."

All of a sudden there was this Friday meeting. It started with an email because our paychecks didn't hit that week. I thought, “That's weird," because I had put in a lot of overtime. Then this email went around that said, "Payroll will be a day or two late at the most." It was a glitch or whatever. Oh, okay, but I've never not been paid in my life. And then two days later, no direct deposit. Three days later, no direct deposit.

Now it's Friday and there's a meeting. So we go to the meeting and the head guy gets up and says, "This is what's going on. The movie's in the hole, big time. They actually don't have any money. But there's a big check coming and our parent company is worth $\$ 8$ billion." They even put $m e$ in front of the group to convince them that there's no way this parent company, which was Discovery Holding Company, is not going to pay people-if just from a PR standpoint-because the holidays were coming up and we were working on a big, giant, multi-million-dollar movie. "The company will make hundreds of millions of dollars!" That's what we were told.

In my mind, I'm thinking they're going to pay us because they promised us these completion bonus deals: if you work until delivery without being paid, you are promised your money, all your overtime, and a completion bonus. At the time, delivery was not far off. People were working to finish the show without pay because we had these guaranteed deals. I found out later that they only gave you the deal if you asked for it in writing. It was only a handshake deal for a lot of people, which is amazing to me. But it didn't matter. When you go bankrupt, all those contracts are worth their weight in paper. So, boom. We deliver the last shot, everything is final, and then there's no money.

One guy got angry and they had to call the cops. He was the quietest guy, too, but he just flipped his lid. He's got kids, a house, they owed him something like $\$ 22,000$. Christmas is coming. I remember him saying, "I can’t even buy Christmas presents for my children." Also, I found out later that they didn't pay the Canadian staff as much as the American staff. The Canadians earned less than half of what the Americans did.

I was owed a lot of money and couldn't believe this was happening. I went to Maine for the holidays. I was sitting at my mom's kitchen table with my laptop and I started writing emails - to Variety, to the Canadian film commission, to the Canadian Ministry of Labour. At one point I called Brendan Fraser's manager, just to make people aware. David Cohen at Variety wrote back, saying, "We're going to write about this. This is news. What's going on? The company owes its artists $\$ 1.3$ million? Can you get anyone else to talk?” It was hard getting other people to talk, but we managed to get a few. 
We're going with a major Hollywood publication because the writer wants the exclusive. And then one day I get this email that says-and I know it by heart because it hit me so fucking hard-it says, "The paper has decided that another visual effects company closing and artists not getting paid, however sad, is happening frequently enough that it's not that newsworthy anymore."

I was like, what?! Just because it's happening more often it's suddenly not newsworthy? As in, people are tired of reading about this? This is huge! So I copy and pasted that into a Word document that eventually became a press release that I did myself. It's still on my website.

Off goes the press release. Right away the writer calls me and he is furious that I took what he called a "private" email and put it in a press release. I said, "It was a rejection letter; there's nothing private about that. It's not from you. The paper told you to write that. It's not you deciding." He got back to me later, after everyone calmed down, and said, "The paper will write something but you have to rerelease your press release without that quote in there." So I put it to our group, saying, "What do you want me to do?" They go, "Take it out! We need coverage." I took it out. But the paper still didn't write anything.

About a week and a half later I get a call from a woman with the New York Post. Yes, finally! She's a fast-talking New York gal and she says, "We're running your story! Is it true Brendan Fraser never called you back?" I say, "Yes, but there's a whole lot more to our story." "But that's the angle!" I say, "I don't think Brendan Fraser ever got the message." She asks me a few more questions and I think she's going to write this big comprehensive article, but it ends up being on page 6 of the Post. It has a picture of Brendan Fraser holding a camera and simply says that we didn't get paid and we called him and he's not helping us.

I'm reading it and my cell phone rings. "Dave Rand?" "Yes." "This is Brendan Fraser. What the fuck is going on?!" That is exactly what he said. And I thought, "My god!" And then I thought some of my friends might be playing a prank on me so I asked, "Where were you born and where were you raised?" I had read about him and he answered it directly.

I'll tell you that Brendan went to bat for us. Of all the actors who have benefited from visual effects movies, he's the only one who got concerned about the way we were treated. He was not only the star of this movie, but also the executive producer. So, given those two roles, of course he should be concerned that there's a whole bunch of people not getting paid!

He started poking around. He would call me back every couple of days. He'd call me! And he'd say, "I called this guy at Discovery. They didn't believe it was me, either. No one believes it's me! I've hardly ever done anything like this on my own!" Then at one point I get a call from one of his agents in Florida, who says, "You are no longer to call Brendan Fraser." I tell her, "You know what, he calls me." And she says, "We've already spoken to Brendan about that, so any numbers you have, 
delete them." I say, "You know what? I can't hear you over the sound of the wheels turning in your head."

And Brendan just keeps calling. He is really cool. That guy is on my A-list forever. The Post does another story that says he's helping us and then suddenly everyone wants to write about it. Variety calls: "Why did you talk to the Post? We were writing the story!"

Over the long haul, Dave Cohen at Variety became a huge heavy hitter for us. He's become a good friend. It was never his decision not to write the story; he's always been 1,000 percent behind us and now Variety is, too, and so is the Hollywood Reporter, the Los Angeles Times, everybody. Back in 2007, I couldn't get anyone to write about the fact that there were 130 visual effects professionals owed \$1.3 million. It wasn't news. Now, I'll throw a pizza party for the union at Rhythm \& Hues and it'll end up in the press.

\section{What are the chances of the workers getting paid in a situation like that?}

Good question. It's a lot better in the United States because the labor laws are tighter. After I became vocal at Meteor, Brendan Fraser helped me recover $\$ 750,000$ of the $\$ 1.3$ million, which is like a world record for visual effects right now. And that's just because of the media attention. So we recovered that money but usually what happens, especially in Canada, is that you get nothing. Or you get a tiny bit. In March the Canadian film commission said, "We have to do something or word is going to get out that this is a big problem." So they took some taxpayer money and now if you're a visual effects artist and your company goes bankrupt, you get $\$ 3,000$. No matter what happens.

Can you tell us the Rhythm \& Hues story, at least your side of it? As we understand it, that was one of the best shops to work for.

By far. That's why its bankruptcy caused such outrage in the visual effects community worldwide. Rhythm \& Hues was like the Alamo of digital effects in Los Angeles. It was run by John Hughes, who was one of the best people I've ever worked for, just a super friendly guy. We became friends because my office was so close to his and he was an avid follower of all of these causes, both for the VFX studios and for the artists.

Anyway, after taking a break from work for a while, my friend called me from Rhythm, saying, "I heard you're in L.A. You have to come by and see this show! It's a giant water show!" As I said, I love doing water. So when I visited, they showed me stuff from Life of Pi. I thought, "Oh my god, this is awesome."

It was an amazing experience to work on Life of $P i$, but they had to pack the joint, so it was kind of close quarters. I'm used to having maybe one other person in my 
office. In Vancouver, on Transformers: Dark of the Moon (2011), we were like an Indian call center. Fucking horrible. And the temperature soared because they couldn't keep up the air conditioning. They treated us like crap. They didn't care. It's like those guys down in the bilge, rowing the boat, "Throw 'em some more food and shut 'em up!" On Life of $\mathrm{P} i$ the worst of it was it just the somewhat close quarters. They had to bring on such a huge staff to do that movie. It was great that they were employing so many people in the United States, but I could sense right away that some things weren't right.

Bill Westenhofer is absolutely one of the best visual effects supervisors I've ever worked for. He got an Academy Award for Life of Pi. Brilliant. I wished he was directing the whole movie. They say Ang Lee was there more than I perceived, but I never saw him in dailies. Dailies at Disney are called "director time." That's what it should be.

So Bill's doing a great job, but then there's a lot of studio stuff and tension with Ang Lee that I'm not privy to, and suddenly the whole operation goes on hold. And my mother's dying so I have to leave. And then my mom passes and I come back and Life of $P i$ is still on fucking hold. There was another show in-house that they put me on, Seventh Son (2014), but then after a while I'm doing nothing. It was a lot of us doing nothing. And they had to keep the whole staff there because when freaking Fox decides to put the movie back on line, we can't re-muster that talent.

Finally Life of Pi comes back on line, but the studio is ordering all these changes, a ton of them! So Rhythm \& Hues is going to be bankrupted. You can sense it. John Hughes calls a special Friday meeting and I'm thinking, "I've been through too many of these. This is getting old." "Your paychecks are going to stop, but keep working on the movie. If you go home, we understand." There are no jobs in L.A. so where the hell are you going to go unless you want to move to Canada or New Zealand or London or Australia? Where are you going to go? People have leases and homes and stuff, so we're all just hoping for the best. That's why visual effects artists keep working when the money stops. Because you can take our money away but we actually feel married to our work. We start living inside of our shot work. "Take my money away, but don't take my shot away, too, and leave me with nothing." I know that's a weird way to think, but it's valid.

John Hughes was so transparent-he always was. Every Friday he opened the books and went through everything for us. The entire financials were in front of us on an overhead projector and he's there explaining them and answering questions until everyone's satisfied.

\section{The entire staff?}

Yes, everyone who wanted to go: the roto guy, the guy who's running the render queue, the guy who's parking the freaking cars, the guy who drives the van to bring us to our cars. Anyone can go to these meetings as long as you work for 
the company. Toward the end, John was having a lot of meetings. Every time he had something to say, we all had to march over to the biggest room in the facility that could hold five hundred, six hundred people. And he would spell it out and stand there and answer questions until everyone was satisfied. It was heartbreaking. There was a group that filmed all of this. Hughes gave them permission to do it, so there's a documentary coming out [called Life After Pi].

And then comes this Sunday night when my friend Bobby calls me. Bobby's in a panic because he's on a visa and he's being laid off. He's scared to death he's going to have to go back to Lebanon because there are no visual effects in Lebanon and he loves it in the US. He goes, "Did you get the call yet?" "What?" "Yes, they're calling people not to come in tomorrow, it's all going to shit. It's over."

At this point, I'm living in a hotel. I had surrendered to living in hotels because you can't sign apartment leases because you never know what country you have to go work in. And even though I'm considered a good visual effects artist and I've been on staff at five or six different companies, you never know how long it's going to last. So you can't buy a house. You can't even rent an apartment. It's just so flimsy. They've totally forgotten Maslow's hierarchy of needs for creativity. Somebody needs to rattle these film executives and say, "What are you doing? You have these prize racehorses and you're beating them to death."

After talking to Bobby, I drive in the next morning. I'm walking in from where we park, which is an eighth of a mile because Rhythm had expanded so much. Only the original staff got to park close. But John Hughes parked where we all had to park. He drove a little shitty car. He's the coolest guy ever. He's walking in with me, and says, "Oh, good, you're still here! I put a word in." I say, "Thanks! No one called me, but are you sure I'm still working here?" "If you didn't get a call, you're still here, I'm pretty sure." So I go to swipe my card to let us in the gate. My card doesn't work. He says, "Oh, let me get that." His works. I say, "I don't think I have a job." He says, "No, no, no, let's find out. Let's find out."

So we go in and walk up to the front desk. I'm not on the list of people laid off, but my card doesn't work. I go upstairs and am able to log in. This is what life had become: you didn't know what's going on. How can anyone be creative in this kind of world? They've turned California into a creative dust bowl.

In any event, I can log on to my shot, so that's a good sign! But I don't know what I'm supposed to do. So I just start working on what I was doing when I was there last. And then my line supervisor walks by and says, "You're still here, thank god!" He had to walk around to see which part of his staff was still there so he could put together the schedule for the day. He says, "Just keep working, I guess. I don't know." It was a nightmare. And to make matters worse, the studio was constantly asking for changes.

Recently I've been working at Disney, on Frozen. You meet with the director, the decision maker, who says, "I want water to splash up on here and it's going to 
be cool here," and then they have a guy come and storyboard it out. So you have a blueprint and then you go be creative within that structure. And you do version one, maybe version two, and it's final. You move on to the next thing. It's such a joy compared to dealing with version 120 .

That was one of the major problems with Life of Pi. We had no contact with Ang Lee. For example, I am working on a sequence where the main character is petting the tiger on the boat. There are twelve shots and they ask me to add rain to the shots, which involves more than just having little dots go by in front of the screen: it's hitting the tiger, it's hitting the boat, it's leaving wet marks running down the sides, making a ripple in the water around it in little jet drops. So you have to come up with these systems that create this rain environment. And you have to do it in layers, and every shot's a different setup. Bill Westenhofer, our visual effects supervisor, is helping me fine tune the rain. We're playing with it together, we're color coding the foreground, middle-ground, and background rain. We make them red, green, and blue so we can see in the picture which rain is doing what. We're making it look cool. We're syncing it and it looks real! The tiger looks so real, so you feel obligated to make whatever you do as good as that tiger, because you'll ruin the shot otherwise.

We get the twelve shots done and they look great. They're ready to be in the movie, so they're going to show Ang Lee. That was right before my mother died and right before the whole show went on hold. When I come back, I'm on a different show because there's nothing to do for Life of Pi. It was almost done. But then I walk into this other artist's room one day to talk to him and see this girl I know next to him, working on my rain shots. I ask, "I thought those were final?" She says, "Oh, you didn't hear? Ang Lee saw the sequence and said, 'Why is it raining?"” So they took the rain out and then they showed the new version to Ang Lee and he said, 'Let's put half of it back in."

So there you go. That's three months of my time making that rain, fine tuning it, making it just right. And then two months of this girl's time taking it out. And I don't know how long it took to put half of it back in. I didn't work on it. And I'm sure they didn't understand my side because the software we use, Houdini, is like an erector set. I mean, you build stuff from scratch. Every time I've seen an artist pick up another artist's Houdini shot, they usually just go in and start over, because it's like, "I don't know what the fuck he was doing."

Toward the end of the Rhythm \& Hues days, it was sad. Just sad. There's a shot in the documentary where John Hughes is being interviewed in his office. He's all choked up and saying, "You know, it was always about the people." That's the real nature of the guy. I would've worked for him forever. He's the reason I kept working when my paycheck stopped. Because I really wanted to see his company make it, one way or the other. A lot of people did. 
Ten days before Life of Pi won the Oscar for Best Visual Effects, Rhythm \& Hues filed for bankruptcy. What was the impact of that?

Scott Ross, former CEO of Digital Domain, tweeted, "I had a dream about 500 visual effects artists marching the Hollywood Walk of Fame, protesting the Oscars." I remember reading it, thinking, "Wouldn't that be great." And then I started thinking about it again on the Thursday night before the Oscars. I thought, "You know what? I'm not a sign-carrying guy. I've never pictured myself on strike. I'm an artist. I'm creative. Maybe there's something else I can do." And then I thought, "Let's see how much it costs to have the Goodyear Blimp fly over with a sign." So I went online and it's like \$20,000 and it's booked already. But if you Google "Goodyear Blimp signs," right underneath it there's this company called Air Signs. It's a plane with a banner. I'm like, "Whoa, $\$ 1,100$. Fuck. I can put that on my credit card right now."

So I tweet something like, "Hey I'm having a plane fly over the Oscars with a banner for visual effects. I need some help coming up with a slogan for the banner." A reporter for Los Angeles Times, Richard Verrier, calls me immediately, he's so excited. I hang up with him and the Hollywood Reporter calls. I hang up with them and Variety calls. Everybody was reading my tweets. And they're getting retweeted.

Then VFX Soldier sends me an email: "Heard about the plane. Don't you think that's a little over the top?" And he wasn't making a pun. A lot of people thought it was kind of wacky but it ended up being the spark. A lot of people started emailing me, "Hey, we should still rally." Then the girl who fixed my rain shots, she comes in and says, "I really admire what you're doing. How can I help? Are you doing a rally? I hear you're doing a rally." I wasn't doing a rally; I was going to fly a plane over! But I say, "Let's do a rally. You're good on Twitter, right?" I barely tweeted anything in my life. And she says, "Yes, we'll make up a Twitter thing for the rally and find out what people want to do."

I suggest we meet at Hollywood and Vine, the most famous intersection in the world, right? So I get in my car and drive over to talk to the local police. I say, "We're going to have a rally for the Oscars, is that legal? Do I have any permits to pull, or what?" They say, "No, as long as everyone stays on the sidewalk. And by the way, you can get closer than Hollywood and Vine." I ask, "Can you help us do that?" And I explain it's about jobs, and they say, "Sure, we'll help you." They assigned to us twelve officers practically in riot gear. They were like punctuation marks at the event; it was awesome. It made us look important to have the cops there like that.

We had five hundred artists show up, which was amazing considering there are hardly any artists left in L.A. And it was such short notice, from Thursday 
night until Sunday. Not only are there hardly any artists left, but there was real fear among those still in town. Back in 2007 I couldn't get anyone to talk to the press, even anonymously. Suddenly we had people willing to have their faces out in public with a sign. We had many issues but it boiled down to the same three things: it's subsidies, it's bidding, and it's a poor creative environment that does not even benefit the studios themselves. We're trying to show them that they are blowing it. Those issues were presented on posters and signs. Some people brought their kids and whatnot. It was a hugely successful rally.

We want to prove that the movies that are the most profitable are the ones where the director directs the visual effects with scrutiny and in real time, with the meter running, as they do on set. If you want to change the lighting setup on set, someone is there telling you how much that decision will cost you. Like Frozen or The Lego Movie (2014): the director was there, the production was treated like a movie set, you barely get past version two, you're done. You move on. Because everyone knows exactly what they're doing. And there's no bidding because it's an in-house creation.

Are you saying that independent shops should go away? That VFX crews should be internalized within the production structure itself?

That's a very viable model. That's how feature animation works, right? They move from one show to the next. They accumulate and nurture their talent. They keep it in house, under one roof; it's all human interaction. Disney Features, DreamWorksno outsourcing for their work. They've both tried it, and it wasn't as great as they thought. Not that it won't work or they're not still trying it, but we didn't do Frozen that way. They didn't outsource anything on The Lion King (1994).

You've talked about living in hotels and you've mentioned mobility. Can you talk about the toll this takes on artists?

I'll tell you about my friend from Lebanon, the one who panicked when he got laid off from Rhythm \& Hues. He paid something like \$15,000 to get an American visa that could let him stay beyond an employer's visa, and that was inches away from going through when he got the news of his layoff from Rhythm. But the visa went through. Now he's got a life in Los Angeles. A longer-term visa, a car, a lease, a girlfriend. But there's no work. The only place he can go is Canada. So he finally gets his American visa, but he has to move to Canada to work.

At the rally we had at DreamWorks where Obama spoke, there was a woman with her three kids. The kids were holding a sign saying, "Mom, why are we moving to Canada?" It's hard to imagine. I don't have a wife and kids. I don't know how they do it, to be honest with you. I've got a friend in New Zealand. He 
transplanted the whole family there. They were in a panic. They had a home in Santa Barbara but had to sell it and move to New Zealand. He doesn't even know if he's going to be kept on because he's on an at-will contract. There's no obligation. So he doesn't want to buy a place in New Zealand. He's renting a place. His kids are in school and they make friends, but not too many because they don't know how long it's going to last. There's no stability. Ultimately you've got artists more concerned with their stability than their shot work. You can't do that. It's just a bad recipe for creativity.

Do you have a long-term contract with Disney?

Nobody in our business these days is on anything but an at-will contract. It's become an American standard. From the conversations I've had, I can tell Disney wants to keep me around. So I actually had the confidence to sign a lease for one full year on an apartment. Frozen did really well and I know I did great work for it, and I feel a hundred times more creative now than I have in years. 